Социолошки преглед, vol. XLII (2008), nо. 2, стр. 241-260

Milovan Vuković

Technical Faculty at Bor, University of Belgrade
UDK: 321.1

Original Scientific Paper Received: 12. 6. 2008.

\title{
INTERNATIONAL WATER DISPUTES AND COOPERATIVE RESPONSES TO WATER STRESS
}

International fresh water resources now ocupy a prominent position in international affairs and are recognized as a legitimate concern of conflict studies. Numerous scholars, policy-makers, and activists alike have suggested broadening use of the security concept beyond its traditional geo-political and military forms to also consider environmental threats that seriously jeopardize human well-being.

This article analyzes conceptual and theoretical arguments that have been made for the management of international environmental issues - such as, for instance, water disputes over international fresh water resources (rivers). Although the above assumptions about water conflict seem to be illuminating, there has been need of a more detailed explanation and understanding of cooperation over international rivers. However, the very conceptions of conflict and cooperation are ambiguous, and, not very convincingly handled in the literature.

In contrast to conflict, cooperation - the main subject in this inquiry - receives less analytic attention, and, consequently, it is less understood as a concept. This study suggests a three-fold typology of cooperation: voluntary, induced, and imposed cooperation.

Keywords: International water disputes, types of conflict, types of coopretion.

\section{Introduction}

Conflicts between and within states over fresh water resources pose an interesting dilemma for scholars and policymakers alike. Often these conflicts are intractable, due to competing claims over water and other economic and social goods, making cooperation difficult. The prevailing wisdom within the international community and international law is to maintain the existing territorial borders of states - the principle of territorial sovereignty. On the other hand, environmental resources, including water, do not recognize political borders.

Sovereign countries guard and protect their water resources with all available means. The rivers thus have become a battleground. The main obstacle to a quick solution is the sovereignty of states (Vajpey 1998, 8). Walker $(1990,8)$ asserts that the historically determined concept of sovereignty simply displaces any other potential political community. Elsewhere, Liftin (1998) considers that sovereignty 
Milovan Vuković, International Water Disputes and Cooperative Responses...

discourse is not appropriate in the ecological context, given the contrast between political and physical-geographical maps of the world. Buzan (1991, 103) clearly summarizes, claiming that conventional meaning of security is regularly highly contested "whenever the image of the state as a referent object for security fades because a novel source of insecurity, such as global environmental change, is not recognizable". This is especially true with an environmental stress striking international rivers and lakes.

However, lakes and rivers, as renewable resources, are linked in "highly complex, interdependent system with many nonlinear and feedback relations" (Homer-Dixon et al, 1993, 38). The overconsumption of any renewable resource can lead to multiple, unforeseen environmental problems and sudden scarcities when the system passes a critical threshold. Human actions have an effect on scarcities of renewable resources in three principal ways. First, people can reduce the quantity or quality of these resources faster than they are renewed. Second, population growth can be the culprit of scarcity. (Within the next five decades, the human population is likely to exceed ten billion, and global economic output may rise five times.) The last main cause is the distribution of resources within a society. Mostly, as a result of these three processes, scarcity of water may increase dramatically (Gleick, 1991; 1993; 1998). Consequently, the overall area of intensively cultivated land may drop, as well the water eco-systems and the number of species they sustain. All these factors create conditions for environmental stress, (including water stress), which may further influence four types of consequences: political, economic, social, and demographic (Falkenmark, 1990).

There are a number of definitions of water stress. The figure of 1,700 cubic meters of water per person per year has been adopted by most hydrologists as the cutoff between a state being water stressed and a state being reasonably comfortable. If a country has less than 1,000 cubic meters per person per year, water is a scarce resource. One could object to this seemingly high threshold since no one was really using the full 1,700 cubic meters. Moreover, this is only one part of the story. When rain-fed agriculture, for instance, is added to the total water balance, many places approach 1,700 cubic meters.

The political significance of cooperation over international fresh water resources - rivers in this study - stems from water's unique importance and three other less salient characteristics of water. These are, according to Frey $(1993,54)$, scarcity, maldistribution, and sharing. Most scholars have focused on the increasing scarcity of fresh water resources, and, consequently, identified it as a major obstacle to cooperation (Nasrallah, 1990; Gleick, 1998).

In contrast to conflict, cooperation - the subject of this paper - receives less analytic attention, and, consequently, it is less understood as a concept. At this point, the definition of cooperation suggested by Frey may be satisfactory for the present analysis. It states that cooperation means "coordination of behavior among actors to realize at least some common goals" (Frey 1993, 57). I suggest a threefold typology of cooperation: voluntary, induced, and imposed cooperation. 
Социолошки преглед, vol. XLII (2008), no. 2, стр. 241-260

Voluntary cooperation refers to an integrated, holistic approach to water resources planning and management (Moigne, 1996). The scope of the planning activity depends on the degree to which political entities can agree to share data and to develop options that, if implemented, could have significant impact on their jurisdictions. Thus, voluntary cooperation entails a reduction of sovereignty, and, consequently, makes it very difficult to achieve. In this study, however, the term voluntary cooperation refers to any content of common plans determined directly by the two parties in the aftermath of a conflict over allocation of transboundarywater resource.

The other two forms of cooperation - imposed and induced - may involve a third party. However, there is a significant difference between imposed and induced cooperation. In the case of imposed cooperation, the primary communication pattern is between parties and an arbiter, panel, or judge. Each party presents a case to the arbiter, panel, or judge, who makes a decision. The decision, however, may be binding or not binding. In this study imposed cooperation refers to the situation when one of the riparian countries with a power preponderance - a hegemon - shapes and dictates the overall tone of cooperation.

Unlike imposed cooperation, induced cooperation always includes a third party through facilitation and/or mediation. Here, the objective is to encourage a direct communication pattern between the disputants. Through this form of cooperation, the parties can jointly diagnose problems, create alternatives, and own agreements. Admittedly, the basic contribution of a third party is to separate the processes of "dialogue" and the "content of dialogue" (Priscoli, 1996, 27).

Further analytical differentiation requires a careful assessment of the relationship between: type of conflict (strategic or symbolic) and cooperation, power and cooperation, and linkage of issues and cooperation. The essential question in the "strategic versus symbolic" typology (derived from Rotham's theory, 2001) is whether water is seen primarily as a just commodity or primarily as a public good, which implies also its sharing. The depth of this gap may vary from case to case. In symbolic conflicts, instead of tangible interests, non-material factors dominate; most frequently those expressed through "images", "perceptions", or "frames". Under this condition, direct cooperation is less likely to occur (Rouyer, 1997, 5859), and this "dichotomy of perceptions" (Salman and Uprety, 1999, 300) makes water negotiations very difficult.

As conflict is by no means always or inherently negative, cooperation is not always positive. Sometimes, efforts to cooperate lead to conflict. In short, the basic assumption is that environmental disputes do not necessarily cause conflictive behavior but more often that they promote cooperation. However, this is not to say that it is easy to achieve, and, more importantly, to maintain the achieved form of cooperation.

Therefore, assuming that states cooperate, the central question of this study is to analyze conditions that determine the form and dynamics of cooperation over international fresh water resources. Cooperation can emerge either from symbolically or 
Milovan Vuković, International Water Disputes and Cooperative Responses...

from strategically framed water conflict. The focus here is on cooperation related to the subset of transboundary water-sharing conflicts - those revolving around actual or imminent increases in water diversions within either upstream or downstream countries.

\section{Responses to Water Stress}

Determining the water stress indicators and perceptions of states involved in a conflict is necessary in order to predict how states and the international society institutions respond through cooperative efforts. This sub-section focuses on responses available to: (1) states involved in conflict, (2) other states, (3) regional organizations, (4) international society institutions such as the United Nations, international financial institutions (the World Bank, the International Monetary Fond), and, (5) non-state actors (environmental groups, epistemic communities, and media).

\section{Responses of States Directly Involved in a Conflict}

States involved in a particular environmental conflict can respond essentially in two different ways depending on the type of insecurity. I use Buzan's (1991) notion of insecurity as a combination of a threat and a vulnerability. In order to achieve security, a state can respond to environmental stress in at least two ways: (1) to eliminate or reduce an environmental threat, acting unilaterally and cooperatively, and, (2) to reduce its vulnerability, acting unilaterally or cooperatively (Sooros, 1994).

There are a number of ways to define vulnerability (Cutter, 1996, 531), sensitivity, a creeping environmental problem, and threshold (Glantz, 1998), resilience (Adger, 2000), and other related terms in regard to environmental stress. In respect to sensitivity and vulnerability, the "theory of interdependence" (Keohane and Nye, 1977) could be analytically very useful for our analysis of states' responses to water conflict. According to Keohane and Nye (1997, 12), sensitivity refers to "degrees of responsiveness within a policy framework - how quickly do changes in one country bring costly changes in another, and how great are the costly effects", whereas vulnerability means the "relative availability and costliness of the alternatives that various actors face". Thus, sensitivity assumes that the policy framework remains unchanged. Whereas sensitivity remains constant over time, vulnerability can decrease, which makes it practically more important than sensitivity.

The Singapore case clearly demonstrates the notions of sensitivity and vulnerability. This "city-state" has never been self-sufficient in water because of its high population and small size. The country is highly dependent on water supplies from nearby Malaysia. However, relations between the two states have been, for a long time, shadowed by economic competition, political, religious, and ethnic different- 
Социолошки преглед, vol. XLII (2008), no. 2, стр. 241-260

ces. Striving to reduce her vulnerability in the case of eventual unilateral action by Malaysia, Singapore has also launched a campaign to increase water supplies and to reduce consumption through an aggressive water management plan. The program includes also new desalination plants that would produce water at about eight times the cost of current supplies (Gleick, 1998, 110).

However, to reduce vulnerability based on agricultural dependence on abundant water supplies is a much more difficult task. The slow pace of "re-configuration" of agriculture, as Biswas et al $(1997,26)$ call it, is influenced by several factors. First of all, the principle of acquired rights in the use of international water resources provides incentives neither to conserve water nor to use it more efficiently. For instance, in Egypt, agricultural water is priceless; but, both Egypt and Jordan, due to old water infrastructure, waste too much scarce water. Second, the agrarian sectors of Middle Eastern societies have all nurtured vested interest over time. Biswas et al $(1997,27)$ note that the kibbutz movement in Israel, very important to the concept of a new Zionist society, still exercises some claims to special treatment in terms of subsidies. Third, there are the political costs of re-configuration. For instance, Syria's Ba'ath Party regime is often described as relying on a peasant base.

The concept of vulnerability, or sensitivity, is more applicable to sudden environmental changes than to those occurring in a relatively long time-frame. For the latter, the concept of "creeping environmental problem" (CEP) and threshold are more appropriate. Glantz's definition $(1998,27)$ of the CEP refers to degradation in the environment as a result of "long-term, low-grade, and slow-onset cumulative processes"; for instance, river pollution during the long-time period. Due to small, incremental changes, societies as well as governments do not recognize changes severe enough to mobilize them to treat their environments any differently than they had earlier. Not surprisingly, such changes may be viewed rather as environmental transformation rather than degradation. This is why, according to Glantz, we need to identify and recognize "thresholds of awareness" of environmental change (See Table 1.).

Glantz notes that the initiation of awareness of environmental change can come from a variety of sources - a farmer, a scientist, a policy maker, or a news reporter. Who will be the first, however, depends on the region and type of the "creeping environmental change". Although many scholars acknowledge the "uncertainty factor" tied to many environmental degradation processes and the positive role of scientists in reducing contested issues, the opposite view is also a valid assumption. Namely, science produces uncertainty. Grundmann (2001) points out that the interpretative approach dominant in the humanities and some social sciences also plays a significant role in sciences. Here, as Grundmann $(2001,24)$ puts it, a scientist may dispute "the validity of the data, the relation between data and interpretation, and the interpretation". In environmental threat controversies such as, for instance, the impact of large dams on biodiversity, the involved parties will argue about the trustworthiness of data and their interpretation. 
Milovan Vuković, International Water Disputes and Cooperative Responses...

The type and intensity of the states' responses are also dependent on particular domestic perception of a threat, determined by the uncertainty ${ }^{5}$ of the environmental degradation process, specific norms, culture, religion, and other ideational elements. However, when ideas gain in importance, as I mentioned earlier (symbolic values), the conflict between parties involved in an environmental conflict may be tougher to resolve and chances to approach the "traditional possibility curve" are not promising (Priscoli, 1996, 24). Basically, ideas have become part of the problem, not part of the solution.

\section{Table 1. Creeping Environmental Problems and Thresholds.}

Steps of Awareness Key Tenets

Threshold 1:

Awareness of change

Threshold 2:

Awareness of a CEP

Threshold 3:

Crisis awareness

Threshold 4:

Awareness of the need to act

Threshold 5:

Action
- Changes may be noticed by individuals at the local level but may not be seen as a threat to local or regional authorities. Changes are seen as benign, and as easily reversible.

- The recognition by an individual or group that environmental change has become a problem. The raise of issues of risk acceptance, risk avoidance, and risk-making. The attention of regional and national policymakers.

- The problem has reached a crisis stage: a crossroad or critical turning point.

- Concerted action to cope with the problem. Only the international and national communities can help local communities to cope with the CEP. Economic and scientific controversies exist.

- Four goals: (1) slow down the rate of creeping environmental change, (2) arrest the progression of the change, (3) reverse the direction of the change, and, (4) restore the system.

Source: Glantz, 1998, 30-32.

Thus, if we have both strong conflict between cognitive orientations and strong conflict between special interests, then, according to Grundmann $(2001,20)$, the outcome will be a "deadlock". To go from deadlock to "technical problem-solving", 
Социолошки преглед, vol. XLII (2008), по. 2, стр. 241-260

following the Grundmann typology, actors have to reduce simultaneously their special interests and cognitive orientations. In this case, not often desired, the available instruments are standards. If the conflict between special interests is increased and conflict between cognitive orientations is decreased, the result is "bargaining" and the instrument is compensation. Finally, the opposite scenario (strong cognitive orientations and weak special interests), or "integrative bargaining", occurs when the common good orientation becomes dominant. This mode of conflict resolution has the advantage of allowing a switch to both bargaining and technical-problem solving because it allows for a much wider range of exceptions than the other modes. Therefore, cooperation, at its roots, is not a technical issue, but a social one. Social relations, in turn, are framed, as Nalven $(1986,793)$ notes, by "cultural expectations of what is correct and acceptable".

Biswas et al $(1997,19)$ contend that "asymmetry of the benefits" of cooperation in river basin development is very often an unbridgeable obstacle to achieving an agreement. When water is the only topic of negotiations, as these authors state, "gains and losses become apparent in a very real sense". This asymmetry may exist across time as well as in relative degrees of dependence on the resource. Thus, during the process of "voluntary cooperation", some riparians might be more interested in a quicker solution while others can choose to wait. When such a scenario exists, a possible response of involved parties could be what Biswas et al (1997, 22) call "multi-good bargaining". Some of examples are: Iraqi oil for "Turkish" water, Syrian control of Kurdish insurgents raids into Turkey in partial exchange for Euphrates water, and the like.

\section{Cooperation over Fresh Water Resources and International Law}

Perhaps the most serious obstacle to voluntary cooperation among involved parties, or "unassisted cooperation" (Priscoli, 1996, 26), is international regulations dealing with water resource issues. The international law governing the multiple uses of international water resources is far less developed than the law relating to the conduct of war and military occupation. Given the international context, however, inefficiency caused by interdependent water uses cannot be resolved through a single government's policies. Upstream countries, as Nakayama (1998, 183) observes, tend to see little benefit from increasing or maintaining the flow and quality of water for downstream countries. Therefore, with effective international water-use rights established by treaty, countries may make decisions considering the consequences for other basin countries.

However, international water law is ambiguous and often contradictory, and no mechanism exists to enforce principles that are agreed upon (Wolf and Hammer, 1998, 136). In fact, international water law did not begin to develop significantly until after World War I. Over time, four major legal principles concerning the sovereignty of the countries have evolved: (1) the Harmon Doctrine or the principle of absolute territorial sovereignty, (2) the principle of absolute 
Milovan Vuković, International Water Disputes and Cooperative Responses...

territorial integrity, (3) Condominium or common jurisdiction, and, (4) the principle of equitable utilization.

According to the Harmon Doctrine, a country has the right to use the fluvial waters which lie within its territory without any limitation whatsoever, regardless of the effect of this utilization on the other countries. This theory is named the "Harmon Doctrine" after Judson Harmon, Attorney General of the USA, who expounded it in 1895 during a dispute with Mexico over the utilization of the waters of the Rio Grande. The United States used this principle in its relationships with Canada regarding the exploitation of the Milk and St. Mary Rivers and the basin of Lake Birch (Barberis, 1986, 213). Since living upstream allows significant advantages, the Harmon Doctrine has often been adopted by the upper riparian countries. Yet, this concept, which disagrees with international law, was denied by the USA a few times after it was used. ${ }^{1}$

Lower riparians prefer the principle of absolute territorial integrity, which means that a country cannot utilize the waters of an international river in a manner which might cause any detrimental effects on co-riparian territory. This principle was used by the Kingdom of Bavaria in a dispute with Austria and by Egypt at the Nile Commission in 1925. Egypt, later on, retreated from this position (Barberis, 1986, 213). This concept favors the position of downstream countries.

Between these two opposing approaches stand two remaining principles. Condominium or common jurisdiction of all riparians over the whole international river or river system aims at limiting a country's freedom of action over the utilization of transnational rivers. The application of this rule would mean that a country would need to get prior consent from the co-riparians for all projects managing waters. The intent of this principle is to point out the mutual development of a river basin by all riparian countries.

Finally, the fourth principle of equitable utilization allows the use of a river's waters to the extent that this does not harm other riparian countries. This principle is widely applied in the international legal community. The Helsinki Rules, defined by the non-governmental International Law Association (ILA) in 1966 (Bourne, 1996), are based on this principle.

The Helsinki Rules on the Uses of the Waters of International Rivers contain six chapters and provide guidelines for "reasonable" and "equitable" sharing of a common waterway. The guiding principle of the Helsinki Rules is found in Article IV: "Each basin [emphasis added] is entitled, within its territory, to a reasonable and equitable share in the beneficial uses of the waters of an international drainage basin". The Helsinki Rules, however, do not exactly define the criterion for reasonable and equitable sharing of transnational water resources. For example, Article $\mathrm{V}$ at the beginning of Chapter 2, lists no fewer than eleven factors that must be considered in defining what is reasonable and equitable: (1) "the geography of the basin including, in particular, the size of the drainage area in the territory of each basin state; (2) the hydrology of the basin including, in particular, the contribution of water by each state; (3) the climate affecting the basin; (4) the past 
Социолошки преглед, vol. XLII (2008), по. 2, стр. 241-260

utilization of the waters of the basin including, in particular, existing utilization; (5) the economic and social needs of each basin state; (6) the population dependent on the waters of the basin in each state; (7) the comparative costs of alternative means of satisfying the economic and social needs of each basin state; (8) the availability of other resources; (9) the avoidance of unnecessary waste in the utilization of waters of the basin; (10) the practicability of compensation to one or more of the co-basin states as a means of negotiating settlements over conflicts among users; and, (11) the degree to which the needs of a basin state may be satisfied without causing substantial injury to another state." Although these criteria are useful, there is no hierarchy among them; rather, they are to be considered as a whole (Wolf 1998, 136).

Another international organization working on a set of rules for sharing transnational water resources is the International Law Commission (ILC), a body of the United Nations (McCaffrey, 1996). Since 1971, this organization has been developing the Law of the Non-Navigational Uses of International Water Courses, and, by 1992, some thirty-two articles had been approved. Finally, the 1997 United Nations Convention on International Watercourses established, for the first time, a set of codified principles to guide riparian countries in the allocation of international water resources. Derived from the concept of equitable utilization, the 1997 convention obligated states to utilize international watercourses in an "equitable and reasonable manner".

\section{Responses of Other States and International Organizations}

Although neither the Helsinki Rules nor the ILC Rules are legally binding, the principle of equitable utilization of international river basins has become the most widely advocated principle in water resource conflicts (Kliot, 1994, 9). Many of the conflicts over international water resources have been resolved on the basis of the above-given rules. There are more than 280 treaties that regulate the use of common water resources (Wolf and Hammer, 1998). Most are bilateral rather than multilateral. ${ }^{2}$ Treaties are brought about mostly using the joint decision-making methods, either directly between the states involved (negotiation) or with the help of a third party (mediation). (For more information on these agreements, see the Transboundary Fresh Water Dispute Database (http://terra.geo.orst.edu/users/ tfdd/) - a project of Oregon State University. It contains the full text of 150 waterrelated treaties and 39 interstate compacts in the United States). ${ }^{3}$

Treaties and river commissions have achieved a significant level of success, probably because they precisely fill the gaps left in generalized international water law. Of course, for any dispute over water resource management, a readily prepared solution should not be expected. In other words, as Hayton $(1982,132)$ acknowledges, "just as war is too important to be left to the generals, water law is too important to be left to the lawyers".

Another important issue is securing such international agreements and putting 
Milovan Vuković, International Water Disputes and Cooperative Responses...

them into practice. Very often this is not an easy task. Basin states in the less developed world, for instance, may lack the capacity to develop and manage their own portion of a shared river, lake, or aquifer. The difficulty can also arise from the "veto power", when a riparian country can veto another basin country's project in an international water body. Obviously, there is a need for involuntary responses, that is, "imposed" and "induced" cooperation (Biswas et al, 1997, 22) which may bring a third party into the bargaining process.

Experience has shown that the involvement of third parties in a negotiation process can "facilitate dispute resolution, guide complex bargaining toward acceptable outcomes, and help maintain balance and commitment by riparian countries to the negotiation process" (World Bank 1994). The role of mediator(s) can be played by international global-governance organizations, international financial organizations, regional organizations, or states not directly involved in an environmental conflict. The effectiveness of various mediators depends on the particular issue being considered (long-term or short-term environmental impacts) and whether a technical problem-solving approach or wider context (including security concerns) is present.

I assert that when wider security issues cloud the water dispute, regional organizations and states tend to be more involved in conflict resolution. However, this does not necessarily prove the efficacy of mediation. The efforts of the United States and the Arab League during the 1950s, for instance, to mediate the water dispute (over the Jordan and Jarmouk Rivers) between Israel, Syria, Jordan, and Lebanon were fruitless. The failure of the Johnston negotiations presumably affected Israel's approach to future negotiations with her Arab neighbors. Rouyer $(2000,123)$ observes that Israel learned that "negotiations with committees of the Arab League conducted by Eric Johnston allowed the most militant states (primarily Syria) to dictate the outcome". Jordan, although a member of the Arab League, had her own specific interest in terms of disputed water resources. Consequently, both states decided to pursue their own unilateral water management policies and, recently, to practice direct negotiations with each other. The unsuccessful American mediation efforts demonstrated the difficulties of applying economic and environmental solutions to political problems. In line with this, Rouyer $(2000,124)$ asserts: "Perhaps the most relevant lesson from the failure of the Johnston negotiations for the Oslo peace process is that political accommodation must come before economic cooperation and that security concerns need to be eased before technical solutions can produce results".

More frequently, however, wealthier states respond to water stress in the less developed world by offering significant financial aid for a variety of purposes. For instance, in order to reduce the impact of the Aral Sea environmental disaster, several countries helped the region: Germany, the United States, Japan, France, and India (Tsukatani, 1998, 69). Germany proposed DM 1.3 million for a comprehensive environmental survey and for water and soil research at the mouths of the Amy Darya and Syr Darya Rivers. In October, 1994, US Secretary of State Warren 
Социолошки преглед, vol. XLII (2008), no. 2, стр. 241-260

Christopher promised a $\$ 15$ million USA aid package to improve the environment around the Aral Sea and the Semipalatinsk nuclear testing zone.

Sometimes, however, financial help is not unconditional and may be used as a coercive means. In 1953, when the Israeli government unilaterally acted in the Upper Jordan River Basin at expense of Syria, the Chief-of-Staff of the United Nations Truce Supervision Organization (UNTSO) on the scene called on Israel to halt the diversionary work on the disputed site unless it could reach an agreement with Syria. The Israeli plan was to divert the Upper Jordan River at Jisr Banat Ya'qub in the central demilitarized zone with Syria. Since Israel continuously ignored these calls, on October 20, 1953, American Secretary of State John Foster Dulles announced publicly that the United States Government would withhold earmarked foreign aid until Israel abided by the request of the UNTSO (Rouyer, 2000, 112). Two weeks later, Israel stopped work on the disputed site and the American sanctions were immediately lifted; ironically, just a couple of months earlier (March 1953), Israel was successful in pressuring the United States government, with the support of friends in Congress, to terminate the Bunger plan. This plan, developed by Mills Bunger, an American engineer, advocated building a storage dam on the Yarmouk, at Maqarin on the Syrian-Jordanian Border, and a second dam at Addassiya near the Israeli-Jordanian demarcation line.

Because of these shortcomings of regional organizations, Nakayama (1998, 185) emphasizes a more effective role of international financial organizations. He asserts that the objectives of international efforts are: (1) to help riparian countries to address their problems with international watercourses, (2) to remove the obstacles to priority development activities that are usually held hostage by disputes over shared water resources, and, (3) to reduce inefficiencies in the use and development of scarce water resources caused by the lack of cooperative planning and development.

Indeed, in many instances, international organizations acted effectively. Biswas et al $(1997,23)$ state that "to-date, the most effective agents of induced cooperation have been multilateral funding institutions, particularly the World Bank". The World Bank was effective in the mediation of conflicts in the Nile River Basin (1959), the Ganges River Basin (1995), and, particularly, in the Aral Sea region (1992). In fact, as Tsuneo Tsukatani $(1998,68)$ notes, the cooperation of five Central-Asian states - Kazakhstan, Uzbekistan, Turkmenistan, Kyrgyzstan, and Tajikistan - with international society is the "only way to cope with the environmental problems in this area".

What makes the World Bank, or other multilateral organizations, so effective as a third party? Nakayama $(1998,186)$ states that international organizations such as the United Nations University (UNU), the United Nations Environmental Programme (UNEP), or the World Bank, have many advantages because each of these can: (1) act as an independent broker; (2) provide leadership inherent in its international role in donor coordination; (3) catalyze the mobilization of official as well as private funding; (4) provide an important channel for gaining access to 
Milovan Vuković, International Water Disputes and Cooperative Responses...

expertise; (5) be creative in promoting appropriate process solutions; and, (6) help to ensure systematic evaluation of alternative solutions through the appropriate use of analytic techniques.

\section{Cooperation and Linkages}

Environmental water conflicts have a common theme - linkage. In this study, I address this aspect of international politics in terms of its effectiveness in regard to cooperation. This effect may be both detrimental and beneficial. For instance, Mueller (1979) asserts that linkage is most often inefficient or unfair. Schwarzer (1998) identifies linkage as one of three factors of influence in his "Process Model of Conflict Settlement". Schwarzer's notion of linkage refers to "addition and subtraction of issues" in regard to the distribution of costs related to an agreement or to an unsettled conflict. Among factors influencing the calculation of costs and benefits are: (1) priority of issues, (2) relative gains, (3) crisis, and, (4) time pressure. The last factor - time pressure - may be of great importance for reaching agreement.

The literature on linkage politics also considers its positive effects. According to Tollison and Willett (1979) and Sebenius (1983), by bringing together functionally unrelated issues, governments can improve their position by making concessions on issues they care little about in exchange for concessions on issue that are economically or politically of greater importance. Lohmann $(1997,39)$ points out that a "credible" commitment to cooperate at the domestic level has the potential to spill over to the international level and vice versa. Therefore, linkage has a two-fold effect; it can improve or undermine the prospects for cooperation. When the latter is the case, governments are then better off "delinking domestic and international issues" (Lohmann, 1997, 39).

\section{Power and Cooperation}

The Neo-Realism paradigm assumes that the absence of central authority in the international system has an impact of the willingness of states to engage cooperation. For Neo-Realists, the behavior of states is a reflection of their power and capabilities in an enduring pursuit for security. This emphasis on the anarchical nature of the international system predisposes states toward conflict and competition. However, anarchy, "impedes cooperation through its generation of uncertainty about the compliance of partners" (Grieco, 1998, 48). Thus, for NeoRealists, cooperation in the world of anarchy is an anomaly.

Despite these pessimist views of world affairs and given the long-lasting character of some water conflicts, Lowi (1993, 11), in her book Power and Politics, points out two factors that may induce states to minimize the salience of the inter-state conflict in the area of international water resources: 
Социолошки преглед, vol. XLII (2008), no. 2, стр. 241-260

First, states which need the resources in question and are (heavily) dependent upon the basin waters will be motivated to cooperate with some or all of the riparians. This is especially the case when access to the water is linked to security concerns. ...

Second, and employing a variant of the theory of hegemonic stability in which the relevant 'structure' is the distribution of power [emphasis added] in the river basin, if the dominant power in the basin will benefit from regional cooperation in water utilization, it will take the lead in creating and maintaining a regime, and will enforce compliance with its rules. ... However, the dominant power will have no interest in basin-wide cooperation if its superior power resources coincide with a superior riparian position.

The combination of these two factors resulted in a cooperative agreement between Egypt and the Sudan on the Nile Waters. On the other hand, the second factor describes the case of Turkey and the dispute in the Euphrates Basin (Lowi, 1993, 10).

Among non-material power capabilities within the issue-power distribution (in this case, international water resource management), hydro-geographical position seems to be the most important in terms of increasing overall power capabilities and in terms of influencing cooperation. Actually, three absolute riparian positions need to be distinguished: upstream, midstream, and downstream. The state which is farthest upstream will have no obvious incentive to cooperate - it can exploit as much of the water as it chooses unilaterally, regardless of downstream needs. In contrast, downstream states like Egypt, irrespective of their relative power capabilities, will seek a cooperative solution, because, "given their inferior riparian position, they are needier than and, at least in theory, at the mercy of those upstream" (Lowi, 1993, 10). ${ }^{4}$

For the sake of cooperation, it is fortunate that few states in the Middle East (Ethiopia, Egypt, Turkey, and Iraq) can adopt consistent legal standings because their hydro-geographical positions are themselves varied (Waterbury, 1994, 41-42). For instance, Syria is mid-stream on the Euphrates and the Orontes Rivers but it is upstream on the Jordan River. Syria, as Waterbury (1994) notes, may support the Palestinian claim for full control of the surface waters of the West Bank, the bulk of which currently drain into the Israeli coastal aquifer. On the other hand, Syria itself is the beneficiary of a cross-frontier aquifer (the Ras al-'Ain) that drains from Turkey into northern Syria. This variability of legal stances may be a crucial obstacle in cooperative efforts that Turkey and Syria have recently made.

However, the midstream states like Syria have several ways of playing their roles. For instance, coalition formation, strongly influenced by riparian's hydrogeographical position, may alter these relations. Frey (1993, 61-62) identifies the two most common coalitions: (1) that of the midstream and downstream states versus the upstream nation, and, (2) that of the upstream nation and its immediate neighbor(s) - brought off by favorable treatment from the upstream state, versus those still farther downstream. 
Milovan Vuković, International Water Disputes and Cooperative Responses...

\section{Responses of Non-State Actors}

In order to include all possible responses to an international water stress, we need to consider the role of world society (or civic society), especially those related to non-governmental environmental organizations (ENGOs) and epistemic communities. The latter are defined as "networks of knowledge-based experts" (Haas, 1992, 1) whose communications relate not to national but to international policy coordination. The members of an epistemic community are strong actors at both the national and international level, and, as Haas $(1992,4)$ asserts, "to the extent to which an epistemic community consolidates bureaucratic power within national administrations and international secretariats, it stands to institutionalize its influence and insinuate its views into broader international politics" (emphasis added by Sullivan, 2001, 16). This element - institutionalization - is the third and last within a three-part causal logic of the epistemic framework. The first two stages are the "uncertainties" faced by policy-makers and the "interpretation" of these uncertainties by experts (Haas, 1992, 3).

There is a general agreement among scholars that these transnational networks have an important influence on international environmental politics by shaping the agenda, by playing a role in the negotiation process, and by improving implementation. The latter activity is not negligible given the circumstances that all the types of cooperation analyzed earlier - voluntary, imposed, and induced - do not guarantee an effective implementation. Yet, despite the contribution of epistemic communities in resolving the uncertainty problems, some scholars express a serious skepticism regarding their objective specific weight within the policy arena.

For instance, Oran Young $(1994,96)$ has three criticisms. First, studies on epistemic communities lack a clear notion of the bargaining process through which international agreements are usually created. Second, the inverse influence of those with material power and those with scientific knowledge is misrepresented in favor of the power of ideas. Third, Young $(1994,94)$ rightly points out a "constant danger of falling in the trap of post hoc reasoning, finding evidence of consensual knowledge in cases of success in regime formation and falling to locate epistemic communities in cases of failure". Merton (1973) has argued persuasively that scientific data may be instrumentalized for pre-existing political options and that policymakers and scientists influence each other. For Sullivan $(2001,168)$, the epistemic community theorizing is one of the most recent "waves of idealism" in IR theory - the globalization discourse is the last one.

Finally, the existence of "adversary science" (Zürn, 1998), that is, raising the controversial issues, may undermine trust in the arguments of the epistemic community. Such controversy may be, for instance, the opposing estimates of the time required for the river recovery (self-purification) after a heavy pollution incident. The controversy with cyanide and heavy metals in the Danube River and the Caspian Sea problem are two of the most recent examples. 
Социолошки преглед, vol. XLII (2008), no. 2, стр. 241-260

The continuous, prolonged drop in the level of the Caspian Sea, for example, caused a panic that reached its peak in the 1970s. Many scholars published their long-term water-level projections based on a variety of approaches. The projections based on the forecast of water withdrawals seemed to be most accurate, and, consequently, the conclusion was: the Caspian Sea would continue to fall. For not very clear reasons, researchers in the 1970s believed that water withdrawals in the Caspian Sea, mainly for irrigation and to fill the large water reservoirs, played a decisive role in variations in the water balance. Nevertheless, the reality was quite different. Humans were responsible for only 10 percent of all variations in the Caspian Sea level!

In fact, instead of long-term decline, the Caspian Sea region has witnessed a sharp water level increase: 2.1 meters since 1978, and an additional $13.5 \mathrm{~cm} / \mathrm{yr}$ rise is anticipated through 2030. In Iran, the impacts on its flat coastal landscape have also been considerable. McNellis and Schweitzer (2001, 112A) identify this set of problems on the Iranian side of the Sea: "The physicochemical properties of waters reaching surrounding rivers and wetlands have changed; floral and faunal habitats are being damaged; seawater intrusion has destroyed agricultural lands as well as numerous buildings and residential areas; sewage and waste disposal sites have been flooded; and the hydraulic slope of rivers is changing". In addition, a major increase in coastal population by 2010 is expected. Iran's interest in protecting its coastal resources provides, as McNellis and Schweitzer argue, an example of a security challenge with international dimensions. Apparently, had more reliable scientific evidence been obtained earlier, the states in danger could have taken a more effective policy choice: a "precautionary" principle of action instead of "wait-and-see" approach.

Does this mean that scientists involved in such controversies are doing "adversary science"? Not, at all. As Reiner Grundmann (2001, 23) has argued, the logic of scientific knowledge is inevitably tied to bias problems. The production of data starts from preconceptions (bias) and the mobilization of bias often occurs during the interpretation of empirical evidence (data). In order to achieve the status of certified knowledge, bias has to disappear. Since only nature is supposed to be the judge of contradictory scientific statements, we tend to trust data more than interpretation. But, as Grundmann $(2001,24)$ notes, "data can only be produced with the help of interpretation: every research starts with some implicit assumption, preconception, or bias".

\section{Conclusion}

Most of environmental conflicts in the area of water management, as used examples in this analysis demonstrated, are highly contextual - these conflicts possess the differences between disputants not only in terms of strategic (material), but also in terms of symbolic (non-material) values attached to the subject of a 
Milovan Vuković, International Water Disputes and Cooperative Responses...

dispute. Among these symbolic elements, it seems that the difference in perceptions between disputants has a decisive influence on the overall dynamic of a conflict and the effectiveness of the involvement of a third party.

More importantly, it represents a challenge for cooperative efforts in order to reduce the impact of "water stress". In this specific policy arena, different forms of cooperation (voluntary, induced, and imposed) depend on both traditional elements of power - military, economic, and political - and power capabilities specific for this issue - for instance, hydro-geographical position of a riparian and the degree of dependence of a country on an other country's water resources. Simultaneously, these two sources of power open the door for application of various linkages whose effectiveness, measured through established cooperative frameworks, can be both detrimental and enhancing.

Further analytical differentiation requires a careful assessment of the relationship between conflict and cooperation. As conflict is by no means always or inherently negative, cooperation is not always positive. Sometimes, efforts to cooperate lead to conflict. In short, the basic assumption is that environmental disputes do not necessarily cause conflictive behavior but more often that they promote cooperation. However, this is not to say that it is easy to achieve, and, more importantly, to maintain the achieved form of cooperation.

\section{ENDNOTES}

1. It is highly questionable whether this doctrine is, or even was, a part of international law. For details see McCaffrey, Stephen C. 1996. The Harmon Doctrine One Hundred Years Later: Buried, Not Praised. Natural Resources Journal. 36(3): 549-590.

2. For instance, of the 18 agreements on the Danube since 1984, only one has been multilateral (Nagy, 1987).

3. For more on international law regarding the international fresh water resources, see: Teclaff, Ludwik A and Eileen Teclaff. 1985. Transboundary Toxic Pollution and the Drainage Basin Concept. Natural Resource Journal. 25(3): 589-612; McCaffrey, Stephen. 1991. International Organization and the Holistic Approach to Water Problems. Natural Resources Journal, 31(1): 139-166; Barberis, Julio. 1991. The Development of the International Law of Transboundary Groundwater. Natural Resources Journal. 31(1): 167-186; Teclaff, Ludwik A and Eileen Teclaff. 1994. Restoring River and Lake Basin Ecosystems. Natural Resources Journal, 34(4): 905-932; McCaffrey, Stephen C. 1996. The Harmon Doctrine One Hundred Years Later: Buried, Not Praised. Natural Resources Journal. 36(3): 549-590); Korhonen, Iris M. 1996. Riverine Ecosystems in International Law. Natural Resources Journal. 36(3): 481-520; and Utton, Albert E. 1996. Which Role Should Prevail in International Water Disputes: That of Reasonableness or that of No Harm. Natural Resources Journal. 36(3): 635-642.

For articles dealing with the applications of international water law to particular cases, see: Benvenisti, Eyal. 1993. Harnessing International Law to Determine Israeli-Palestinian Water Rights: The Mountain Aquifer. Natural Resources Journal. 33(3): 543-568; Caponera, Dante A. 1993. Legal Aspects of Transboundary River Basins in the Middle East: The Al Asi (Orontes), The Jordan, and the Nile. Natural Resources Journal. 33(3): 629-664; Elmusa, 
Социолошки преглед, vol. XLII (2008), no. 2, стр. 241-260

Sharif S. 1995. Dividing Common Water Resources According to International Water Law: The $\mathrm{C}$ ase of the Palestinian-Israeli Waters. Natural Resources Journal. 35(2): 223-242; and Dellapenna, Joseph W. 1996. Rivers as Legal Structures: The Examples of the Jordan and the Nile. Natural Resources Journal. 36(2): 217-250.

4. Based on all the cases studied (from the Middle East), Lowi concludes that cooperation is not achieved unless the dominant power in the basin accepts it, or has been induced to do so by an external power. Here findings, hence, imply the following conclusion: "In the absence of coercion from outside, this [the establishment of a regime] occurs in river basin only if: (1) the dominant power's relationship to the water resources in question is one of critical need, linked to its national security concerns, and (2) it is not the upstream riparian. Cooperation in international river basin is brought about by hegemonic powers" (Lowi, 1993, 203).

\section{REFERENCES}

Adger, Neil W. 2000. Social and Ecological Resilience: Are They Related? Progress in Human Geography. 24(3): 347-364.

Barberis, Julio. 1991. The Development of the International Law of Transboundary Groundwater. Natural Resources Journal. 31(1): 167-186

Biswas, Asit K; John Kolars; Masahiro Murakami; John Waterbury; and Aaron Wolf. 1997. Core and Periphery: A Comprehensive Approach to Middle Eastern Water. Delhi: Oxford University Press.

Bourne, Charles B. 1996. The International Law Association's Contribution to International Water Resource Law. Natural Resources Journal. 36(2): 155-216.

Buzan, Barry. 1991. People, States and Fear. $2^{\text {nd }}$ ed. Hemel-Hempstead, U.K.: Harvester Wheatsheaf.

Cutter, Susan L. 1996. Vulnerability to Environmental Hazards. Progress in Human Geography. 20(4): 529-539.

Falkenmark, Malin. 1990. Global Water Issues Confronting Humanity. Journal of Peace Research. 27(2): 117-190.

Frey, Frederick W. 1993. The Political Context of Conflict and Cooperation Over International River Basins. Water International. 18(1): 54-68.

Grieco, Joseph M. 1988. Anarchy and the Limits of Cooepration: A Realist Critique of the Newest Liberal Institutionalism. International Organization. 42(3): 486-507.

Glantz, Michael H. 1998. Creeping Environmental Problems in the Aral Sea Basin. Pp. 25-52. In: Central Euroasian Water Crisis (ed. by Kobori, Iwao and Michael H. Glantz). Tokyo, New York, Paris: United Nations University Press.

Gleick, Peter H. 1991. Environment and Security: The Clear Connections. The Bulletin of the Atomic Scientists. 47(3): 17-21.

Gleick, Peter H. 1993. Water and Conflict - Fresh Water Resources and International Security. International Security. 18: 79-112.

Gleick, Peter H. 1998. The World's Water - The Biennial Report on Freshwater Resources 1998-1999. Covelo, California: Island Press, California: Covelo, Washington.

Grundmann, Reiner. 2001. Transnational Environmental Policy: Reconstructing Ozone. London and New York: Routledge. 
Milovan Vuković, International Water Disputes and Cooperative Responses...

Haas, Peter M. 1992. Introduction: Epistemic Communities in International Policy Coordination. International Organization. (46): 1-36.

Hayton, Robert D. 1982. The Law of International Aquifers. Natural Resources Journal. 22: 71-94.

Homer-Dixon, Thomas F.; J.H. Bountwell; and G.W. Rathjens. 1993. Environmental Change and Violent Conflict. Scientific American. 268: 38-43.

Keohane, Robert and Joseph Nye Jr. 1977. Power and Interdependence. Boston: Little, Brown.

Kliot, Nurit. 1994. Water Resources and Conflict in the Middle East. London and New York: Routledge.

Liftin, Karen T. 1999. Constructing Environmental Security and Ecological Interdependence. Global Governance. 5(3): 359-377.

Lohmann, Susanne. 1997. Linkage Politics. Journal of Conflict Resolution. 41(1): 3867.

Lowi, Miriam R. 1993. Water and Power: The Politics of a Scarce Resource in the Jordan River Basin. Cambridge: University Press.

McCaffrey, Stephen. 1991. International Organization and the Holistic Approach to Water Problems. Natural Resources Journal. 31(1): 139-166.

McNelis, David N. and Glenn E. Schweitzer. 2001. An Evolving Concept. Environmental Science and Technology. March 1: 109A-113A.

Merton, Robert. 1973. The Sociology of Science: Theoretical and Empirical Investigations. Chicago: University of Chicago Press.

Moigne, Guy Le. 1996. An Integrated Approach for National and Basin-Wide Development Planning: Methods, Prospects and Constraints. Pp. 1-18. In: River Basin Planning and Management (ed. by Abu-Zeid, Mahmoud A. and Asit K. Biswas). Calcutta, Delhi, Bombay, Madras: Oxford University Press.

Mueller, D.C. 1979. Public Choice. Cambridge, MA.: Cambridge University Press.

Nakayama, Mikiyasu. 1998. The Role of International Organizations in the Integrated Management of International Water Bodies: The Activities of the UNU, UNEP, and the World Bank in the Middle East. Pp. 183-195. In: Central Euroasian Water Crisis (ed. by Kobori, Iwao and Michael H. Glantz). Tokyo, New York, Paris: United Nations University Press.

Nalven, Joseph. 1986. Transboundary Environmental Problem Solving: Social Process, Cultural Perception. Natural Resources Journal. 26(4): 793-818.

Nasrallah, Fida. 1990. Middle Eastern Waters: The Hydraulic Imperative. Middle East International. (April): 21-22.

Priscoli, Jerome Delli. 1996. The Development of Transnational Regimes for Water Resources Management. Pp. 19-38. In: River Basin Planning and Management (ed. by Abu-Zeid, Mahmoud A. and Asit K. Biswas). Calcutta, Delhi, Bombay, Madras: Oxford University Press.

Rothman, Jay. 2001. From Interests to Identities: Towards a New Emphasis in Interactive Conflict Resolution. Journal of Peace Research. 38(1): 289-305.

Rouyer, Alwyn R. 1997. The Water Issue in the Palestinian-Israeli Peace Process. Survival, 39(2): 57-81.

Rouyer, Alwyn R. 2000. Turning Water into Politics: The Water Issue in the PalestinianIsraeli Conflict. London: MacMillan Press Ltd.; New York: St. Martin's Press, Inc. 
Социолошки преглед, vol. XLII (2008), no. 2, стр. 241-260

Salman, Salman M.A. and Kishor Uprety. 1999. Hydro-Politics in South Asia: A Comparative Analysis of the Mahakali and the Ganges Treaties. Natural Resources Journal. 39(1): 295-344.

Schwarzer, Gudrun. 1998. The Peaceful Settlement of Interstate Conflict: Saar, Austria, and Berlin. Journal of Peace Research. 35(6): 743-757.

Sebenius, James K. 1983. Negotiation Arithmetic: Adding and Subtracting Issues and Parties. International Organization. 37(2): 281-316.

Sooros, Marvin S. 1994. Global Change, Environmental Security, and the Prisoner's Dilemma. Journal of Peace Research. 31(3): 317-332.

Sullivan, Michael P. 2001. Theories of International Relations: Transition vs. Persistence. New York: Palgrave.

Tollison, R.D. and Willet, T.D. 1979. An Economic Theory of Mutually Advantageous Issue Linkages in International Organization. International Organization. 33: 425459.

Tsukatani, Tsuneo. 1998. The Aral Sea and Socio-economic Development. Pp. 53-74. In: Central Euroasian Water Crisis (ed. by Kobori, Iwao and Michael H. Glantz). Tokyo, New York, Paris: United Nations University Press.

Vajpeyi, Dhirenda K. (ed.). 1998. Water Resources Management: A Comparative Perspective. Westport, Connecticut London: Praeger.

Walker, R.B.J. 1990. Security, Sovereignty and the Challenge of World Politics. Alternatives. 15(1).

Waterbury, John. 1894. Transboundary Water and the Challenge of International Cooperation in the Middle East. Pp. 9-64. In: Water in the Arab World: Perspectives and Prognoses (ed. by Rogers, Peter and Peter Lydon). Harvard University: The Division of Applied Sciences.

Wolf, Aaron T. and Jesse H. Hammer. 2000. Trends in Transboundary Water Disputes and Dispute Resolution. Pp. 123-148. In: Environment and Security (ed. by Lowi, Miriam R. and Brian R. Shaw). London: MacMillan Press Ltd; New York: St. Martins's Press, Inc.

Wood, Alexander; Pamela Stedman-Edwards; and Johanna Mang. (eds.). 2000. The Root Causes of Biodiversity Loss. London: Earthscan Publications Ltd.

World Bank. 1994. A Strategy for Managing Water in the Middle East and

North Africa. Washington, D.C.: World Bank.

Young, Oran. 1994. International Governance: Protecting the Environment in a Stateless Society. Ithaca, N.Y.: Cornell University Press.

Young, Oran. 1997. Global Governance: Drawing Insights from the Environmental Experience. Cambridge, MA: MIT Press.

Zürn, Michael. 1998. The Rise of International Environmental Politics: A Review of Current Research. World Politics. 50(4): 617-649. 
Milovan Vuković, International Water Disputes and Cooperative Responses...

Милован Вуковић

Технички факултет, Бор

Универзитет у Београду

Резиме

\section{МЕЪУНАРОДНИ ВОДНИ РЕСУРСИ И КООПЕРАТИВНИ ОДГОВОРИ НА ВОДНИ СТРЕС}

Међународни водни ресурси заузимају у новије време значајно место у међународној политици и постају легитиман предмет разматрања и у студијама конфликта. Бројни научници, субјекти јавне политике, као и активисти, предлажу проширење концепта безбедности, који би ишао даље од његових традиционалних геополитичких и војних облика, како би се размотриле и еколошке претње које озбиљно угрожавају човека.

Овај рад анализира концептуалне и теоријске аргументе изведене за управљање међународним еколошким питањима, попут, на пример, несугласица око газдовања међународним водним ресурсима (рекама). Мада поставке о конфликту око река могу бити вредне истраживања, постоји потреба за детаљнијим објашњењем и разумевањем кооперације у овој области. Међутим, и сами концепти конфликта и кооперације су поприлично нејасни и недовољно уверљиво елаборирани у литератури.

Насупрот конфликту, кооперацији - главном предмету разматрања овог рада посвећује се мања аналитичка пажња те је она, због тога, мање разумљива као концепт. У том смислу, ово истраживање представља одређени допринос. Наиме, у раду се полази од типологије кооперације која обухвата три облика: добровољну, индуковану и присилну кооперацију. У раду је домонстрирано да тип кооперације зависи углавном од типа конфликта (симболичког или стратегијског), те да је кооперативне аранжмане много лакше успоставити него одржати.

Кључне речи: еколошки конфликти, типови конфликта, типови кооперације. 